THE CONVOLUTED LOGIC OF CREOLIZATION THE NEW ORLEANS WAY

Author(s): Benton Jay Komins

Source: The Comparatist, Vol. 24 (May 2000), pp. 99-122

Published by: University of North Carolina Press

Stable URL: https://www.jstor.org/stable/44367058

Accessed: 08-02-2019 08:06 UTC

JSTOR is a not-for-profit service that helps scholars, researchers, and students discover, use, and build upon a wide range of content in a trusted digital archive. We use information technology and tools to increase productivity and facilitate new forms of scholarship. For more information about JSTOR, please contact support@jstor.org.

Your use of the JSTOR archive indicates your acceptance of the Terms \& Conditions of Use, available at https://about.jstor.org/terms

University of North Carolina Press is collaborating with JSTOR to digitize, preserve and extend access to The Comparatist 


\title{
THE CONVOLUTED LOGIC OF CREOLIZATION THE NEW ORLEANS WAY
}

\author{
Benton Jay Komins
}

The essay that follows describes some of the cultural ambiguities of the city of New Orleans, which, in its guise of either subtropical Parisian oasis or plague-infested port, has always been multiple, existing as an imaginary destination and a real metropolis. Beyond the specificities of New Orleans, my encounter with "The Convoluted Logic of Creolization the New Orleans Way" tells another story. As a physical and social "inland island" surrounded by pestilential swamps and antagonistic neighbors, this city developed a culture that responded and continues to respond to the social and economic realities of geography, ethnic mixing, and diversity.

In New Orleans, Creole describes a people (peoples) as much as it describes a cultural process. ${ }^{1}$ The same phenomenon that linguistically turned colonial Zweigs into Creole La Branches (a local "German" family name) today integrates East Asian and Central American emigrants into the quirks of the city's culture. I evaluate the fictional parameters of this convoluted creolization odyssey in the work of Ruth McEnery Stuart, Shirley Ann Grau, and Ellen Gilchrist-three exemplary authors who use and manipulate this problematic process to different narrative ends. In addition to these fictional works, I discuss a group of nonfictional texts-travelogue anecdotes, ethnographic work, and a suggestive jazz composition-which describe the experiences of New Orleans' visitors, "permanent residents," and immigrants. I close with a few postmodern reflections that connect New Orleans' logic of creolization to other cultural discussions.

My structure follows the convoluted nature of the topic; avoiding any clear definition, New Orleans' creolization meanders through travel narrative, fiction, ethnic study, and theory. ${ }^{2}$ Rather than presenting a sustained, linear argument that describes what creolization means or represents, I approach the topic from its periphery, borrowing the tropes and images of the works I examine. I organize my encounters with the city's versions of creolization the New Orleans way around suggestions of ideological manipulation, cultural difference, and popular history. These sections yoke texts with different interpretations of the creolization question, highlighting its ambiguities, clichés, and mythic potential.

In New Orleans, "circumstances favored the reciprocal acculturation of Creoles of various lineages," states Joseph Roach in his Cities of the Dead: Circum-Atlantic Performance (1996), "within a unique network of African, American, and European practices" (9). Roach roots the multicultural aspect of New Orleans to the settlement pattern of colonial

Vot. 23 (1999): 99 


\section{CREOLIZATION THE NEW ORLEANS WAY}

Louisiana and the reality of its cultural isolation, from environmental factors to the juridical circumstances of the French colonial Code Noir. Despite the inequities of slavery, Africans and Europeans developed a mutually reliant economy and culture in colonial New Orleans, which consisted of Gallic traditions, Native American memories, and African performances. The city's collective culture later absorbed aspects of Anglo-America. ${ }^{3}$ This colonial interdependence suggests that creolization means more than becoming Creole; the early French settlers, "their" enslaved Africans, and Native Americans added elements to the city's early culture, not as lost ingredients in a local melting pot, but rather as important constituents of a civic culture that hesitantly integrates yet always allows ethnic identities and cultural expressions to flourish. On this inland island, an elusive mechanism integrates different traditions, continually synthesizing European, North American, West African, Caribbean, and Asian practices, myths, and expressions. Beyond colonial history, creolization continues to integrate in a convoluted fashion, allowing both residents and visitors to join the city's local culture while maintaining their differences.

\section{Ideological Manipulation}

A) Ruth McEnery Stuart's The River's Children: The Ideology of Creolized Hope

The New Orleans local color author Ruth McEnery Stuart offers a remarkable expression of creolization in her novel The River's Children: An Idyll of the Mississippi (1904), which romanticizes the lives of newly impoverished New Orleans gentry and their ever-loyal ex-slaves during Reconstruction. In this novel, Stuart's luxurious descriptions of New Orleans flora and fauna and clichéd representations of freed mammies and stoic planters gravitate around the figure of a young woman, Miss Agnes "Blossom" Le Duc, a character or perhaps abstract embodiment of a creolized future in the face of historical upheaval. Stuart introduces Agnes as Blossom, the pampered white charge of Mammy Hannah and Ole' Man Israel. In the topsy-turvy world of post-Civil war New Orleans, two elderly black squatters parent their ex-master Harold's abandoned child in a makeshift levee shack. The black couple worry about their inherited daughter's future: “An' you know, Isrul, you an' me we ain't fittin to raise Marse Harol's chile. Sh'e big enough to study quality manners and white behavior [...] Dis heah cabin on de river-bank ain't no place for my white folks" (Stuart 38-39). Still caught in the shadow of the plantation, Hannah and Israel cannot conceive of a future with their precious "little Miss." Their doting care cannot bridge the caste boundaries between the freedman's struggle and "dancin'-school curtsies." Even though Harold's return is all but impossible (Hannah and Israel both believe that their ex-master is probably dead "an' forgot in some ol" ditch on de battle-field" [Stuart 40]), these two surrogate parents realize that Blossom must return to her white world in whatever state it now

Vor. 23 (1999): 100 


\section{THE COMPARATIST}

exists. But, as often happens in local color fiction, fate intervenes when Blossom's course seems set: "Hannah! Hannah! Heah Mars' Harol'!" (Stuart 101). At the point that Hannah and Israel decide to return Blossom to her "Agnes" future, which corresponds diegetically to the end of the intercalated story of Harold's peculiar circumstances as the family's prodigal son, the beloved father/master returns to care duly for his rightful daughter and his devoted Mammy and Ole' Man. (Stuart plays with the prodigal motif by including a list of Bible stories that Hannah recites to her little charge, ending with the story of "De Prodigum Son.") No longer a landed aristocrat or benign master, the bedraggled Harold must contend with changes in material and cultural conditions.

We ain't dast to give 'er no name, Baby, no mo' 'n jes Blossom. I got 'er wrote down in five citificates 'Miss Blossom,' jes so. No, sir. I knows my colored place, an' I'll go so far, an' dat's all de further. She was jes as much a blossom befo' she was christened as she was arterwards, so my namin' 'er don't count. I was' mos' tempted to call out 'Agnes' to de preachers. When dey'd look to me for a name, seein' it was her right-like as ef she was borned to it; but-I ain't nuver imposed on her. No, sir, we ain't imposed on her noways. (Stuart 115)

Reserving a proper naming to one of her "petigree," Hannah and Israel innocently mark Harold's child with the name/epithet Blossom. The little girl experiences the world through Blossom eyes, that is, through the soft reassurances and homespun wisdom of her Mammy and Ole' Man. Instead of retrieving a hyper-refined future debutante and her ignorant lackeys, Harold confronts a cohesive family unit. Young Agnes belongs as much to the emerging world of the freedman as to Harold's collapsed planter's world. The girl's existence bridges the caste boundaries between her adopted parents' struggle and the gentility of her father's past. Returned to her father, Agnes continues a Creole legacy, yet this legacy now incorporates all the vicissitudes of her Blossom past. This girl fuses the traditions of the ancienne population and the hopes of the newly incorporated. Stuart makes this fusion abundantly clear through both the frame and scenario that directly follow young Agnes's departure from her adoptive family. The framing father who reclaims his lost child is no longer the elegant Harold Guyoso Le Duc en route to the promises of landed inheritances, but an impoverished prisoner in occupied New Orleans. Just as history, in the guise of carpetbagger politics, denies Agnes her father's traditional Creole legacy, nature itself conspires to erase her beloved Mammy and Ole' Man who, the same evening of her departure, are swept into a flash Mississippi flood.

There is yet a final aspect to the girl's heritage of names that expands upon the Blossom/Agnes equation to include the solidity of AngloSaxon, Yankee America.

This magnetic quality - one hesitates to use an expression so nervously prostrated by strenuous overwork, and yet it is well made and to hand-

Vol. 23 (1999): 101 


\section{CREOLIZATION THE NEW ORLEANS WAY}

this magnetic quality, then, was probably, in Agnes Le Duc, the gift of the Latin strain grafted upon New England sturdiness and reserve, the one answering, as one might say, for ballast, while the other lent sail for the equable poising of a safe and brilliant life-craft. (Stuart 150-151)

Agnes's birth mother, who died when the child was an infant, originally came to the Le Duc plantation from Boston. Mammy Hannah divulges aspects of this transplanted woman's saga in relation to the worrisome future of her "little Miss." The surrogate black mother cannot properly arrange for the child's "petigree" christening because this birth mother, Miss Aggie, was a "Numitarium," presumably a Unitarian, at odds with both the adoptive family's folksy inflection of Christianity and the Le Duc's combined Catholic and Episcopalian faith. Beyond religious differences, according to Mammy Hannah, Miss Aggie was different from the other plantation women: She indolently "sipped iced orange syrup or claret sangaree" and "knew the Latin names of much of the flora" (Stuart 76-77). In other words, Agnes's birth mother could combine Creole expectations of ladylike gentility with the rigor of her educated New England past. As Stuart introduces this notion of combined qualities in Miss Aggie, she enthusiastically expounds upon their unique possibilities in a description of mature Agnes. As much as the girl is Blossom and Agnes, she is Aggie, whose legacy includes the independent and integrative mind-set of a Yankee birth mother.

We leave the fiction of Blossom/Agnes/Aggie against its original backdrop:

Part of the ladies' cabin of a old Mississippi steamboat, still shabbily fine in white paint and dingy gilding, which Israel had reclaimed from an abandoned wreck, formed a wing of the building. This, which, with its furnishings, Mammy called 'Blossom's lay-out,' communicated by a door with a 'lean-to' of weather-stained boards, whose mud chimney and homely front formed a strong contrast to the river entrance of white and gold. This grotesque architectural composite would have attracted attention at another time or place, but as one of a class, made to its need of any available material, it passed unnoticed beyond an occasional casual smile of amusement and sympathy. (Stuart 34-35)

This hodgepodge of shanty fittings, faded gilt, and dysfunctional steamboat technology, Stuart's "grotesque architectural composite," encapsulates both the synthetic aspects of the girl's background and the sense that it makes in New Orleans during Reconstruction. Against the seeming historical odds of racial adoption, Creole impoverishment, and motherlessness (Mammy's shanty, Harold's ruined inheritance, and Miss Aggie's tradition of education), Stuart's young heroine prevails, outlining a path for a creolized future. Almost emblematically, this "modern" character represents New Orleans' evolving creolized culture, which, rather optimistically, combines complementary aspects of African-American, Creole, and "Yankee" life.

Vot. 23 (1999): 102 


\section{THE COMPARATIST}

\section{B) Shirley Ann Grau's The Keepers of the House: The Ideology of Creolized Seepage}

The three faces of Blossom/Agnes/Aggie that collectively meet the demands of a changing Louisiana world become a crippling legacy in Shirley Ann Grau's novel, The Keepers of the House (1965). Where Stuart's character can be read as an optimistic response to the realigned racial and cultural orders of Reconstruction, the creolized tradition in Grau's much later work underscores the real racial and economic inequities of mid-twentieth-century Southern life. Grau won a Pulitzer Prize for the novel in 1965, an honor that historically records not only the quality of the work but also its political timeliness as it engages issues at the heart of the then-emerging Southern Civil Rights Movement.

Grau's novel focuses on the cross-generational chronicle of the Howlands, a Southern family that controls the economy of the fictional Madison City. At the center of this dynastic saga is the story of Aimée Legendre, a New Orleans woman who brought Roman Catholicism, Creole ways, and magnate status to the family. While Grau explicitly factors aspects of Aimée's life into the novel, she implicitly develops the theme of her transformative legacy. Abigail Tolliver, Aimée's distant offspring and the novel's narrator, periodically alludes to the family's Creole matriarch.

My great-great-grandmother, the one from New Orleans, had gone landcrazy during Reconstruction [.. . ] Because she was city-born, the stories went, she wanted more and more room in the country. It was she who looked up the old letters and found that the Howland farm had once been called Shirley. She tried to bring back the name; all her papers and diaries referred to it that way. But it hadn't worked, and after her death it went right back to being called the Howland Place the way it had always been. She hadn't changed its name but she had changed its shape and size. And she had bought most of the timber lands that were going to be so valuable. (Grau 154)

Aimée not only brought wealth to the family; she also fractured it:

It went back to the turn of the century, to the time of the Catholic Mrs. Howland [Aimée] from New Orleans. What with her religion and the way her father made his money, the Howland family had not treated her very well; they split into those who would accept her and those who wouldn't. Now she was long dead, but the different cousins went on being cool to each other. (Grau 164)

Abigail understands the present-day splintering of her family around Aimée's differences: In the face of late-nineteenth-century Southern Christian Fundamentalism, questionable money and "popish" rites had the historical strength to cleave the most cohesive of families. Yet, Aimée

Vot. 24 (2000): 103 


\section{CREOLIZATION THE NEW ORLEANS WAY}

Legendre contributes far more to the Howlands than the derisive issues of dirty money and foreign Catholicism.

[.. .] he remembered his Creole grandmother's name for these narrow channels in a marsh: trainasse. He hadn't thought of her in years, that thin silent beak-nosed woman. Her English had remained stilted and formal all her life, she had never seemed quite at home with it. But she had not made any effort to teach French to her children or her grandchildren. She hadn't wanted to go to France either, though she had more than enough money for the trip. She simply hadn't seemed to mind not belonging. She hadn't seemed to mind perching uncomfortably on the edge of her world. . . . (Grau 71-72)

Aimée, as remembered by her immediate descendants and mythologized by her more distant kin, introduces the theme of the secretive outsider into the family. Her grandson, William Howland (Abigail's grandfather), lapses into his trainasse memory immediately before he meets his future mulatto mistress, Margaret Carmichael. Margaret is more than the gratuitous colored mistress; she descends from the Freejacks of New Church (the descendants of valiant slaves who were manumitted because they helped Andrew Jackson defend New Orleans against the British): "They were proud of their station and they kept apart from other Negroes" (Grau 10). As much as she resists the stereotype of the backstreet mistress, proud Margaret also resists the dogged devotion of Stuart's Mammy and Ole' Man. Grau goes to great lengths to portray her character as an individual outside pervasive racist clichés.

The racial ramifications of William and Margaret's relationship frame Abigail's narrative. Like his outsider grandmother, William surreptitiously retreats from the Southern propriety of Madison City; while Aimée retreated into her own unsmiling silence, William opens his arms and household to an illegal colored mistress. The consequences of Aimée's apathy and William's officially forbidden love together foretell the collapse of the Howland estates. When the Howland fortunes are literally crumbling around her, Abigail imagines a conversation with her dead grandfather in which all of the mythic Howlands reappear "like paper dolls drawn from the grave" (Grau 290). These vivified portraits animate the tragedy that is unfolding in the Howland house: white Madison City's punishment for the perceived cultural transgression of Aimée and the "unnatural union" of William and Margaret.

In the eyes of white Madison City, William's "sin" does not center on his relationship with Margaret, but on his act of marrying her.

Negro returns to visit his legal white family. And then a subhead: Past of preeminent citizen comes to light. Gubernatorial candidate involved.

I didn't read the fine print. Instead I looked at the second piece of paper.

It was a certificate of marriage. Between William Howland and Margaret Carmichael. The place was Cleveland. The date was April 1928, two months before Robert's birth.

Vot. 24 (2000): 104 


\section{THE COMPARATIST}

I sat on the bright sunny porch and heard John's words over and over again: "Are you sure? What have you done?" (Grau 259, italics in the text)

Shortly before the birth of their first quadroon child, William and Margaret legally married in Ohio, an action that made their son, Robert, and their two subsequent daughters, Nina and Crissy, legitimate Howland heirs. The same Southern Fundamentalists who shunned Aimée's questionable money and Roman Catholicism privilege mixed-blood illegitimacy over interracial marriage. Long after the deaths of William and Margaret, Abigail bears the burden of their legal transgression. In effect, she must pay for her grandfather's secret of marriage, which made his mixed-blood children legitimate. Mirroring the contradictory standards and self-serving morality of white Madison City (through which Grau obviously critiques Southern racism), Abigail's punishment is trebly cruel for it severs her from her husband, the innocence of her childhood, and her Howland status.

Abigail's husband, John Tolliver, the gubernatorial candidate considered "the brightest hope of the southern segregationists," amasses a constituency through virulent racism. Combining pseudoscientific libel with inflammatory rhetoric, his platform cannot incorporate his wife's family ghost. According to the aspiring Tolliver, "The contents of the average Negro skull is 169 milligrams lighter than the average white skull. His brain casing is on the average some 121 millimeters thicker. $\mathrm{He}$ is simply not suited by nature for equality with the white man [. . .]" (Grau 250). Not only does the presence of quadroon cousins tarnish his "superior" white image, but their legitimate status directly contradicts the laws of segregation. Following the logic of racist traditions and inherited guilt, John blames Abigail for her grandfather William's actions. Her very act of communicating with her grandfather's children is enough to destroy their marriage.

Past her husband's politically motivated condemnation, Abigail must face a town of judges. Newly abandoned, this last of Aimée's heirs meets a lynch mob on her ancestral land:

They were standing there on the lawn, a little group together, their faces expressionless. There was young Michaels, whose father was the pharmacist. Wharton Andrews, the farmer. Les Matthews, who worked at the gin. Joe Harriman from the feed store. Lester Peterson from the hatchery. Abruptly I stopped looking at them as people, and saw them only as shapes. It would be easier that way. (Grau 287)

The men who march onto her property are not hooded members of the Klan; they are the same everyday Madison City residents who formerly paid homage to her wealthy family. The unveiling of William Howland's secret, born in his Creole grandmother's trainasse (itself perhaps a geographical allusion to the convoluted cultural terrain of the creolized south), incites a rationalized frenzy that ends with the destruction of the extensive Howland barns and a mêlée of gunfire.

Vot. 24 (2000): 105 


\section{CREOLIZATION THE NEW ORLEANS WAY}

In spite of the fact that Margaret Carmichael indelibly marks the events that are in the process of unfolding, Abigail does not envision a portrait of her surrogate grandmother in her vivified family cast. "But Margaret hadn't been with them [. . . ] All of a sudden I realized why. She was not one of my ghosts. She would haunt her own children, not me. She was not part of me" (Grau 290). Caught in the pervasive mind-set of her age, region, and class, even Abigail cannot put her colored relations into perspective. While she recognizes her grandfather's decent act, she cannot accept her cousins and "grandmother" as proper Howlands, rooted to the legacy of Aimée. In Shirley Ann Grau's Abigail, the creolized future that Ruth McEnery Stuart posits through her heroine finally shipwrecks on the shore of a biracial family; in this sense, the optimistic Agnes who necessarily incorporates her Blossom past becomes the haunted Abigail who reads the secrets of her creolized family only around "the seepage, the worms of time" (Grau 182). Sixty years after Stuart's imaginary depiction of a multicultural creolized New Orleans, Grau positions the legacy of Creole otherness and racial mixing at the center of a local Southern tragedy, addressing real social and racial inequities.

\section{Cultural Difference}

Arrivée à la Nouvelle-Orléans. Forêt de vaisseaux. Mississipi [sic] 300 pieds de fond. Apparence extérieure de la ville. Belles maisons. Cabanes. Rues boueuses et sans pavés. Architecture espagnole: toits plats; anglaise: briques, petites portes; française: massives portes cochères. Population aussi mêlée. Figures de toutes les nuances de couleur. Langage français, anglais, espagnol, créole. Air général français, et cependant affiches, annonces commerciales généralement en anglais. (Tocqueville 191)

Upon arriving in New Orleans in 1832, Alexis de Tocqueville captures the ethnic character of the city and its inhabitants. The French tourist's stippled verbal images relate everything from the muddy waters of the river to the multilingual chatter on the streets; from the constructed terrain to nuances of the inhabitants' complexions, Tocqueville characterizes this port city as a place of ethnic diversity and racial division. "Le soir au spectacle ... Etrange coup d'œil que présente la salle: première loge, blanche; seconde, grise. Femmes de couleur, très jolies . . . Troisième loge noire (191). ${ }^{5}$ Even when he is comfortably ensconced in the Opera House for a performance of Auber's Le Maçon, in a most Gallic of New World settings, Tocqueville notices the peculiar dynamics of the city's code. In New Orleans, like in colonial Kingston, Havana, and Saint-Domingue (Haiti), the European architectural paradigm of the auditorium came to reflect the three-tier structure of its racial code. As a stylistic exercise and an amusing reflection, Tocqueville's earlynineteenth-century remarks elegantly introduce aspects of the city's ethnic composition and history.

Vot. 24 (2000): 106 


\section{THE COMPARATIST}

Much as this French visitor portrays the city in a painterly fashionthat is, as a series of descriptive flashes-we can begin to experience the peoples of New Orleans around accounts of their respective pasts. Spanning geographical space and time, various works describe the experiences of eighteenth-, nineteenth- and twentieth-century émigrés from Africa and Europe and more recently from Central America and Southeast Asia. ${ }^{6}$ While a thorough survey of these texts lies beyond the scope of my discussion of creolization, a stippled analysis of certain interrelated themes adds an element of historical density to a presentation that would otherwise remain purely bound to aesthetic concerns. Like carefully manipulated speckles and flecks of pigment that have the collective strength to evoke a landscape or pictorial mise-en-scène, a spotty discussion of the immigrant experience in New Orleans underscores the convoluted logic of creolization the New Orleans way. From the struggles of disembarkation to economic and environmental acclimatization, each ethnic account serves as a case study in the integrative possibilities of cultural hybridization.

As a suggestive introduction to New Orleans' ethnic tapestry, Jesse William Nash closes his unpublished dissertation on the city's Vietnamese community with a type of ethnographic envoi, in which he directly relates Vietnamese life not only to the opinions of other ethnic groups but also to the lived actuality of New Orleans.

Anyone interested in doing ethnographic fieldwork in New Orleans cannot but help to become involved in other ethnic groups in the region. Although most folks were aware that I was studying the Vietnamese, the local black and Chinese populations provided me the opportunity to learn about them in the course of my fieldwork. I have relied on their observations, complaints, and confessions to influence my understanding of New Orleans and the Vietnamese interaction with that city. To study the Vietnamese living in New Orleans is also to study the very city they hesitantly call home. (Nash 384-385)

Nash tells us that the contemporary Vietnamese experience in New Orleans, heuristically organized as Confucian, Catholic, and American, serves as a representative case study in the New Orleans cultural trajectory of "hesitant" integration. Nash is not alone in positing an exemplary status to an immigrant community. In his earlier study of the city's antebellum Jewish community, The Early Jews of New Orleans (1969), Bertram Korn argues that the rapid rise of the city's Jewish residents, despite apparent religious and historical obstacles, distinctively highlights how New Orleans acculturates and assimilates qualified individuals. According to Korn,

[The] large scale acceptance of Jews into almost every nook and cranny of social, political and cultural life in addition to the more obvious opportunities of the market place, meant that there was no negative pressure upon Jews to create a congregation or to develop an intensive Jewish life.

Vol. 24 (2000): 107 


\section{CREOLIZATION THE NEW ORLEANS WAY}

[. . .] Certain social and economic factors made New Orleans an exceptional American city in this regard, during this [early-nineteenth-century] period: the turbulent growth of the city, bringing into its midst people of every kind of background and heritage, and turning it into the most heterogeneous city in the country; the strong rivalry of Creoles and Yankees, both sides eagerly seeking both Christian and Jewish recruits; the absence of a tradition of hide-bound, narrow evangelical Protestantism on the one hand, and of defensive, separtistic and suspicious Catholicism on the other; the constant need for men of talent and ability to take leadership in a society where many young men were unambitious, effete dandies; the tremendous economic potential of the city, never really exploited to its fullest, constantly in need of rich imagination and strong direction; the periodic financial crises which shook out the incompetent and the incautious, and made room for risk takers. (Korn 228-229)

Korn states that the same unique cultural, religious, and economic variables that provided opportunities for Jewish settlers to rise to positions of prominence also ensured that the Jewish community would remain loosely organized. Open New Orleans could no better incorporate inflections of traditional Judaism than those of evangelical Protestantism or suspicious Catholicism. Where Jesse Nash explicitly positions his study of the Vietnamese community within the ethnic contexts of the city's black and Chinese communities and the culture of the city at large, Bertram Korn, through his focus on early Jewish New Orleanians, implicitly develops a model of integration that is open to any ambitious group of new arrivals.

Between Nash's explicitness and Korn's implicitness, S. Frederick Starr gives an almost anecdotal vignette of the city's Italian population. Much as for the removed Tocqueville, the incongruities and ethnic peculiarities of New Orleans seize Starr's sensibilities in a manner that would seem to run counter to his academic training. (Starr is a past president of Oberlin College and a Russian and Central Asian scholar, yet the ethnic terrain of New Orleans might seem "natural" to someone acquainted with the ethnic diversity of the former Soviet Union.)

If you are over six feet tall and carry life insurance, here is a sociological experiment to be performed seriatim in San Francisco, South Philadelphia, and New Orleans. First, find a typical local Italian restaurant. Then walk in and let them seat you, preferably near the door. When the waiter comes to take your order, smile amiably and ask for "Wop Salad."

In almost any self-respecting Italian community in the United States, your order will unleash a fury unmatched since the Romans dismantled Carthage. Plates will fly and rococo oaths will fill the air. Your dentist will soon be able to buy that new Mercedes he's been eyeing.

But at Mandina's, Mandich's, Campagno's or any of a dozen other fine Italian restaurants in New Orleans, the experiment will turn out differently. Your waiter will respond to your order by inquiring what dressing you want and whether or not you want a Dixie with your Wop Salad. For in New Orleans, Wop Salad is just a name. If you hadn't ordered it your-

Vol. 24 (2000): 108 


\section{THE COMPARATIST}

self, the waiter might have suggested it with a Sicilian twinkle, and you would be foolish to ignore his advice. (Starr 129-130)

Through his proposed experiment, Starr not only captures the Italian community's pride, he also demonstrates its reliance on the opinions of other ethnic groups. More than a quirky label, "Wop Salad," in New Orleans, inverts a stereotype of denigration. (Restaurateurs and their customers translate the early-twentieth-century xenophobic slur-Without Official Papers-to reflect Italian self-esteem.) It is not coincidental that Starr's twinkling waiter asks if his customer would like a Dixie beer with his salad, as this beverage links this most Italian of New Orleans dishes to the region (the American South), to other immigrant populations (the German-owned brewery industry), and even more important, to other unique local products. In her unpublished essay, "The Germans in New Orleans" (undated), Harriet Stern lists the beer industry as the primary German business in nineteenth-century New Orleans:

By 1900 there were 10 gigantic breweries in New Orleans [. . .] The volume grew steadily [...] Hundreds of Germans found employment in [the] breweries and others were established later [. . . ] As a result beer drinking extended to all groups in the city, and New Orleans stands high among American cities in the per capita consumption of beer. $(12)^{7}$

Like Starr's "Wop Salad," a beer is more than a satisfying drink when one drinks it against the ethnic contexts of New Orleans.

"Wop Salad is the culinary version of the Piazza d'Italia. It is the product of confident people who view their history with nostalgia and good-natured pride rather than bitterness" (Starr 130). With great facility, Starr moves from the peculiar menu of the New Orleans Italian dining room to suggestions of postmodern architecture (through a syncretic cluster of grandiose façades and imperial columns, Charles Moore's Piazza d'Italia commemorates the heroes of New Orleans' Italian community). While contemporary cultural debates seem far removed from the question of creolization (to say nothing about the twists of an Italian dinner in New Orleans), even the mention of history and nostalgia in the context of a contemporary structure invites speculation. According to architectural historian Beverly Russell,

The much-documented Piazza d'Italia in New Orleans, with its classical Roman detailing, was the work of architect Charles Moore, who reported his loss of confidence in Modernism in a seminal book-Body, Memory and Architecture (1977)-coauthored with [. . . Kent Bloomer. It helped to establish new ways of looking at design that would respond to people's needs. Bloomer and Moore drew parallels between the physiological characteristics of people and buildings, noting that a freestanding house with a back and front (body), an empty-space attic at the top (mind), a fireplace and hearth (heart), and a lower basement (implication of the id) asserts the typical American identity. Reaching back into history, they

Vot. 24 (2000): 109 


\section{CREOLIZATION THE NEW ORLEANS WAY}

noted that columns were celebrations of the special human ability to assume an upright stance. Walls proclaimed territoriality. Roofs, even though obviously practical for shelter, served as crowns. These were fundamental concepts in the evolution of humankind. Four columns holding up a roof or four poles holding up a network of thatch or even a piece of cloth formed the basic pavilion, common for millennia as a place of celebration or worship. Christian churches had been built in the shape of the cross for symbolic reasons, their domes signifying heaven. In some ancient cultures, triangular pediments over doorways indicated a head man. In short, numerous codes in design were layered with more meaning than perhaps we were prepared to recognize. (31)

Because it is caught between Nash's explicit and Korn's implicit model (the reliance on the opinions of other ethnic groups and the unusual possibilities open to newcomers with moxie), Starr's experimental privileging of the Italian "Wop Salad" and its connected reflection of monumentality, Piazza d'Italia, articulates an anecdotal formula of creolization that has enough elasticity to open onto larger cultural discussions. Through Starr's suggestion, we can only begin to speculate in which ways his seemingly lighthearted New Orleans immigrant model relates to multiculturalism and the "promise of a 'postmodern,' 'postmale,' 'post-humanist,' 'post-Puritan' world" (Huyssen 194). As an evolving entity, New Orleans' ethnic tapestry shares a pivotal concern of postmodernism, namely "the sociologically significant emergence of various forms of 'otherness' in the cultural sphere" (Huyssen 199).

Like culture, acclimatization is at the heart of creolization the New Orleans way. The survival of nineteenth-century immigrants depended upon real acclimatization to the city's swampy subtropical environment. The historian John Duffy best articulates the imperative aspect of acclimatization in discussing the city's yellow fever epidemic of 1853 :

Like most cities during the first half of the nineteenth century, New Orleans lacked the machinery for collecting vital statistics-a fact which left municipal authorities completely untroubled. Prominent doctors, newspaper editors, and civic leaders were convinced that their city was a veritable health spa. True, they admitted, yellow fever and other diseases exacted a heavy toll, but these fatalities occurred almost exclusively among the ignorant and the dissolute poor. Once a newcomer had passed through the "seasoning" or acclimating process, he would then be virtually immune to the epidemic diseases. (Duffy 6-7)

In New Orleans, acclimatization links culture and climate; historically the process of creolization necessarily represented a synchronized response to social and natural demands.

Let any one coolly reflect that the Fever is killing two percent of the unacclimated population every week, that is from eight to nine hundred out of forty or fifty thousand - and then calculate how long it would take to annihilate this class of our inhabitants. (New Orleans Medical 843)

Vot. 24 (2000): 110 


\section{THE COMPARATIST}

The combination of grossly inadequate sanitary facilities, primitive epidemiology, and limited distribution of material wealth together accounted for the periodic scourge of yellow fever on the city's newcomers. Beyond any abstract implication or cultural curiosity, creolization (in its guise of acclimatization) represented a means of survival.

Survival is at the base of another creolized New Orleans inhabitant who resides in the contemporary city's filthy back lots and alleys: "Was it the piercing eyes of Rag Lady or the clatter of the New Orleans cup that forced him down from the throne into the rug of oppression? Social indignation removes the individual from the ability to choose" (Forsyth 51). An ostensible piece of refuse or by-product of the city, Rag Lady-in a creolized New Orleans context, quite suggestively also known as Madame Rag-presides over a secret domain of vagrants, homeless drug abusers, and formerly institutionalized wanderers. "At first she seems used and haggard, a slave of society, a rug to wipe your social ills upon. But then you see that no one is using her, no one has dictated her schedule, no one has given her a uniform, she is master of her realm" (Forsyth 47). Rag Lady moves through New Orleans oblivious to standards and expectations. The rounds of her daily regimen, which include sleeping in an immense flower-pot, dining on dumpster scraps, and excreting in public fountains, absolutely do not conform to the mythic code of Creole propriety.

Among Rag Lady's minions are two disheveled dwarfs, black women who are perfectly acclimatized to both the environmental demands of the Gulf South and the cultural demands of their vagabond monarch.

They look just like another pile of garbage that has been pushed in some corner, as they sleep like animals, camouflaged from their enemies. Yearround coats that have been rearranged to accommodate tonight's New Orleans weather hang from their human-like frames. (Forsyth 47)

These loyal subjects not only have mastered their Lady's art of dressing in layers (a lifesaving skill in New Orleans where the temperature on a winter day can plunge thirty degrees), they also represent their queen's network of power. (While the women's four eyes provide an essential net of surveillance, the first fruits of their rummaging feed and clothe their sovereign.) Bolstered by nothing other than unsinkable tenacity, Rag Lady perfectly calibrates her existence to the reality of New Orleans' streets by exploiting the efforts of her subordinates. She flourishes because she has taught her two, otherwise hapless and helpless, subjects the skills needed to survive in "her" New Orleans.

The city is beginning to unfold. Buses expel their gases and noise brings an end to the bleakness of the unpopulated strip. The sun and the buses have created a sizzling-polluted neutral ground. Here the representatives of the city will arrive; hating each other; biting at one another with ethnic slurs; pushing and shoving like animals. [. . . Stepping from their cattle

Vot. 24 (2000): 111 


\section{CREOLIZATION THE NEWORLEANS WAY}

cars they emerge onto this no-man's land to act out the stereotypes of their respective ethnic places. The masses have come here to do their bidding upon life's distorted auction block. This is their life, my existence, and our lot. (Forsyth 52)

As absolute queen of the New Orleans homeless world, Rag Lady neither explicitly relies on the opinions of other groups nor implicitly thrives under the city's invitation to resourceful new arrivals. Against environmental factors, the terrors of the street and impoverishment, Rag Lady maintains her imperial mien. Her world of cozy flowerpots, dwarf servitors, and resourceful ingenuity hides behind the everyday New Orleans world of noisy intolerance (an aspect of the city's life that Nash, Korn, and Starr optimistically ignore). Like those of the Vietnamese immigrant, Jewish entrepreneur, and Italian restaurateur, the existence of this most ragged inhabitant, who resides at the bottom of the city's residential, economic, and cultural chains, illustrates the ubiquitousness of the creolization phenomenon. Rag Lady is the critical, acclimatized constituent of New Orleans' civic culture, who assesses her "intolerant" siblings through the cracks and fissures of the city's public façade.

\section{Popular History}

In printed and symbolic maps of traveling America, New Orleans is synonymous with jazz music and "a drunken good time." Travel guides, television commercials, and now the city's various web sites proudly flaunt images of contented visitors, sipping invigorating local cocktails, listening to jazz musicians on the street. To the beguiled tourist, the two parts of this most contemporary New Orleans image-musical savoir faire and the peculiar code that governs alcohol consumption-hold the keys to the city. I contend that the invitations of jazz and drunkenness offer models of creolization that reach beyond New Orleans.

\section{A) An Inebriated Precedent: Thackeray's New Orleans}

Like Alexis de Tocqueville, William Makepeace Thackeray includes the destination of New Orleans in his great travelogue, Roundabout Papers:

As for New Orleans, in spring-time,- - just when the orchards were flushing over with peach-blossoms, and the sweet herbs came to flavour the juleps-it seemed to me the city of the world where you can eat and drink the most and suffer the least. At Bordeaux itself, claret is not better to drink than at New Orleans. [. . .] Find me speaking ill of such a country! When I do, pone me pigris campis: smother me in a desert, or let Mississippi or Garonne drown me! (167-168)

While Tocqueville focuses on the city's racial and ethnic anomalies, Thackeray, almost inebriatedly, relishes the hospitable city's food and superabundant vintages. "When Thackeray visited [New Orleans]," ac-

Vot. 24 (2000): 112 


\section{THE COMPARATIST}

cording to Robert Tallant, "just before the Civil War he found it unbelievable. The citizens, hotels and coffeehouses all extended themselves to the utmost to make the stay of the famous guest a notable one" (265). The British visitor finds the best hedonistic pleasures of Europe in New Orleans. In vino veritas: Can we attribute Thackeray's lavish praise to the tongue-loosening agency of alcohol? Is Thackeray's New Orleans merely a moment of drunken and culinary pleasure in a cycle of otherwise Spartan American travels? (After his experiences in New Orleans this traveler ventured upriver to the then-frontier cities of Memphis, Tennessee, and Cairo, Illinois.) In the traveling imagination, the destination of New Orleans promises some form of sensual gratification. With much fanfare, this promise of gastronomic, musical, imbibed, and other delights begins to creolize the enthralled visitor.

\section{B) Suggestions of Jelly Roll Morton's “Hyena Stomp”}

Keep a lively tempo but "shove in crying whenever you get the chance." Then your listeners can dance and feel the tears behind. This is the master formula of jazz - mulatto knowingness ripened by black sorrow. (Lomax 93) ${ }^{9}$

Ferdinand "Jelly Roll" Morton (1885-1941) - the local musician extraordinaire who helped export jazz from New Orleans-binds Thackeray's sensual promises to the modern culture of the city. Through the figure of Jelly Roll we can begin to read behind the popular tourist image of "the jazzy high" to see how certain mechanisms work to creolize intoxicated outsiders. While Jelly Roll musically represents the notoriety of Storyville (the legal red-light district of New Orleans that existed between 1898 and 1917, whose wanton excesses clever Bourbon Street proprietors now imitate), he also presents an accessible theory of jazz. Historically enveloped in the cloying vulgarity of an illustrious Storyville Madame's "house," the steamy simplicity of Jelly Roll's stomping and syncopation invite even the most musically limited individual "to dance and feel the tears behind."

Jelly Roll himself attributed aspects of his music both to the palette of peoples who passed through Storyville and to violent events: "See all kind of people came through those joints-longshoremens, roustabouts, cowboys, Yankees, and every kind of woman in the world. I seen plenty of knife-and-pistol play. Killings was a common affair [. . . It cause me to dig down deeper in my music more so yet" (Lomax 91). In his position as whorehouse "perfessor" (token mulatto piano player), Morton saw beyond the confinement of his colored caste. In the legalized world of Storyville, background, profession, and class decided only which house, and for that matter what sexual acts, an individual could buy. In earlytwentieth-century New Orleans, this certainly deviated from the cultural norm that divided people along racial lines. In this world of lascivious capitalism, violence inevitably erupted:

Vol. 24 (2000): 113 


\section{CREOLIZATION THE NEWORLEANS WAY}

Throughout the entire period [1898-1917], while the city fathers passed ordinances, the rough, tough "ladies of the evening" were attracting hundreds of flatboatmen, "Kaintucks" [Anglo-Americans from Kentucky and other states north of Louisiana], and the assorted underworld types with which port cities have always been well stocked and were "processing" them with assembly-line precision and then turning them out penniless into the dawn. The arsenal of weapons used to extract the loot ranged from cajolery to cold steel, through an inventory of pistols, "knockout drops," and blunt, heavy objects. (Rose 8 )

Against the horrors of a legally circumscribed quarter of vice, open to all, Morton admittedly channels his anxieties into music. An aspect of his music's language - much like his "perfessed" recipe for jazz, "mulatto knowingness ripened by black sorrow"-grapples with the strange Storyville relationship between exploitation and bodily pleasure.

The brief composition "Hyena Stomp" (c. 1927) is exemplary, not only as an uproarious sensual invitation but also as Jelly Roll Morton's participatory jazz event that continually recreates the creolization phenomenon. ${ }^{10}$ Like most early jazz compositions, Morton's "Stomp" combines European harmony with West African and Caribbean dance rhythms, like the juba, calinda, and bamboula. Beyond this obvious creolized mix, the composition juxtaposes vocalization with instrumentation; bouts of hysterical laughter (perhaps the shriek of the namesake hyena) punctuate a changing series of brass and woodwind fragments. "That's terrible, Jelly": A false start breaks the juxtapositional pattern at the beginning. The same voice that squeals with laughter also announces that the composition must begin again. Through this incorporated technique of fallibility, Morton musically integrates empathy into the pattern of "Hyena Stomp." Outside listeners not only experience dissonant feelings through jarring syncopation (the placing of accent or stress on a normally unaccented section), they "identify" with the composer through the technique of linguistic admission. This moment of empathy with Jelly Roll (orchestrated by Jelly Roll) teeters between the seeming incoherence of the laughter and the shock of the instrumentation. Far beyond the promise of a jazzy high with its implicit memory of transgressively legal Storyville boudoirs, "Hyena Stomp"'s musical confusion (voiced admission of inadequacy, embedded ferocious laughter, and unsettling instrumental technique) acclimatizes its listeners to the "strange" cultural variables of New Orleans. In microcosm, its three-and-one-half-minute duration quite economically reproduces creolization the New Orleans way: I suggest that Jelly's play with words, laughter, and abrupt hoots musically evoke the struggling immigrant, the raucous revels of tourist brochures, and finally the "stippled" Tocquevillean effect of the city's multiethnic residents. Through its musical syntax and its local, Storyville specificity, "Hyena Stomp" aesthetically functions as one creolized mechanism that integrates different traditions, not only synthesizing historical European, West African, Caribbean, and African American practices, but also

Vot. 24 (2000): 114 


\section{THE COMPARATIST}

continually inviting unaccustomed outsiders to experience the city's convoluted culture.

\section{C) The Carnivalesque Dimensions of Ellen Gilchrist's "Drunk Every Day"}

Some of the creolized ambiguities that Jelly Roll promises to his listeners' musical tastes, the contemporary author Ellen Gilchrist promises to her readers. Gilchrist brings to fiction aspects of the New Orleans of traveling America, most specifically the possibility (and consequences) of living the perennial drunken good time.

To begin with it was Mardi Gras and my friends and I were drunk every day. There was no reason why we should not be. We were the privileged ones. The ones who did not have to work or take care of our children or do a goddamn thing we didn't want to do. My name is Rhoda Manning, by the way, and I am older now and wiser. Still, I don't regret the life that I have lived. I don't regret a goddamn minute of it. I left no stone unturned. I will never have to sit back and say, Where did my life go? (Gilchrist 227-228)

In Gilchrist's short story, "Drunk Every Day," the fictional Rhoda Manning recounts the most remarkable events in her Mardi Gras day of 1975. Within the contours of this story, the now insightful, narrating Rhoda realizes that the drunken details of her exploits (muted by a hippie sensibility) also narrate the common saga of the idle upper-class New Orleans housewife; like other bored ladies who play tennis, buy cars, and gentrify houses, Rhoda's life during carnival gravitates around a series of lavish meals and alcohol-soaked evenings. Her description of Mardi Gras eve includes an elegant inflection of the touristic drunken good time. "Black waiters serving champagne and drinks. Jazz playing on a stereo. [...] The children of the house sitting on the stairs in their best clothes watching the grown people get drunk" (Gilchrist 230). In the company of other fine uptown New Orleanians, Rhoda staggers around an acquaintance's mansion, moving to a jazz beat, setting a fine example for a group of future socialites.

Against this world of chic and booze (and on Mardi Gras, dexedrine), the alcohol-influenced Rhoda draws connections between bad luck and the rape of her friend Sally: "There is a strange thing about being involved in a rape. You don't feel guilty like you do after a car wreck or something like that. A rape is an act of God. It's a matter of being in the wrong place at the wrong time. It's not as if I could have stopped it by being more caring or aware" (Gilchrist 243). Briefly abandoned by her "dear" friend Rhoda, who pays a quick visit to an eccentric neighbor, Sally happens upon a rapist, or so the logic of Rhoda's foggy account goes. Whereas Rhoda staggers through the Mardi Gras madness with only the occasional irritations of her children's disappearing pranks and her husband's seriousness, Sally's carnival bout ends in physical violation.

Vot. 24 (2000): 115 


\section{CREOLIZATION THE NEW ORLEANS WAY}

Sally functions as Rhoda's delightful backdrop, her "good enough" excuse for a drunken romp.

More about Sally. She was a twenty-five-year-old swimmer who had outgrown the sport. She had come in second in the NCAA for Tennessee the year she was a junior in college. That had been the peak. It had been downhill ever since. Still, she could run as fast as I could and once she had an affair with a sportswriter I had a crush on, and on the basis of that we had become fast friends. She liked the illusion of a home I had created with Eric and I thought she was good enough for me. We liked the way each other looked. She was tall and blond and pretty and I was extravagantly well dressed. She was my running buddy in 1975. I liked to have a good-looking slightly younger woman riding shotgun at all times in those years. For one thing it kept Eric from saying anything when I got drunk. He was too polite to pout in front of strangers. (Gilchrist 229)

Through Rhoda's relationship with the equally wealthy, bored, and drunken Sally, Gilchrist critiques the dangerous flip side of the New Orleans high. Beyond the fantasy of drunken creolized delight elegantly coded into Rhoda's lavish lunches, soirées, and fashionable drug abuse, she forces us to problematize the drunken reality of Rhoda's "shotgun" partner, the magnificently equal Sally. However nostalgic, Rhoda's strange detachment from her friend's rape and, moreover, her frank exploitation of Sally's instrumental value (at least where her husband Eric is concerned) underscore the irresponsibility and crippling limitations of living in a perennial drunken state.

Lest we believe that Gilchrist simply collapses her character's acts of rationalized exploitation into a critique of New Orleans' intoxicating invitation, Rhoda quite explicitly identifies with the politics (that is, with a capital P) of the antiwar movement:

Let me put it this way. Race relations had taken a back seat to the Vietnam war. The war had redrawn the alliances, had brought the young people into an understanding that transcended race. Hell, no, we won't go. Won't go into your armies, your factories, your law firms, fuck you. For better or for worse I had sided with the young in this matter. I hardly had a friend over thirty. (Gilchrist 233)

Even in her web of drunken ennui, Rhoda allies herself with the fashionable resistance politics of the moment. In the position of utmost hypocrite, she conveniently forgets not only the entitlement that her wealthy husband's law firm provides, but, more important, the entire experience of her segregated Mardi Gras world. While Rhoda and Sally can visit the black Mardi Gras Indian den ("We were lucky white people who had been invited to the warehouse where the Tchoupitoulas Indians got ready for their stomp" [Gilchrist 233]), no African American, except for select servants, enters the venue of their alcohol-soaked evenings. In much the way that Rhoda reduces Sally's rape to fate and place, she

Vot. 24 (2000): 116 


\section{THE COMPARATIST}

brackets the racism of her privileged uptown world. Through this inclusion of Rhoda's political engagement (reduced to one concise paragraph), Gilchrist expands upon the perilous flip side of the New Orleans invitation-the creolizing promise of a drunken good time-to reflect upon the endemic, yet correctly veiled, racism of the elite, white partying set.

When drunken Rhoda and soon-to-be ravaged Sally stumble upon a displaced Englishman, Gilchrist fictionally reproduces the exemplary creolizing moment.

A handsome man with a British accent stopped us on the street. "Do you know the way to the Royal Orleans?" he asked.

"Who are you?" I answered. "Why are you wearing a business suit?"

"I'm an engineer. I came on business. Lucky to get here for this, wouldn't you say?"

"Why do you want the Royal Orleans?"

"Because I'm staying there. I've lost my way."

"We'll take you home. I'm Rhoda and this is Sally. We are looking for a psychiatrist."

"You need to talk to one?"

"We are in love with one. We'll call him from the hotel. We'll get him to come and have a drink with us. Come on along. Don't lose sight of us." (Gilchrist 236)

On a randy quest for the irresistible brother of a friend, the two women encounter Robert, a lost British engineer who chanced upon Mardi Gras: "He was a game and very well-behaved Englishman. He didn't ask questions. He just went along" (Gilchrist 237). Passive Robert immediately becomes part of the women's entertainment. From hotel room antics to wild abandon on the streets, the women guide their seduced objet trouvé through the afternoon. This scenario appears to be the very stuff of New Orleans travel brochures, which promise visitors a warm reception: "I added. 'I'm committed to your Mardi Gras. I want you to experience the real thing.' 'Good of you to want me,' he answered. 'Perhaps I will be of some help' "(Gilchrist 239).

Robert leaves the street celebrations to return home with Eric. Despite the fact that the committed Rhoda's two sons have disappeared, she desires to give her surprise guest a real taste of Mardi Gras. Attuned to every exciting possibility or chance happening, this drunken heroine shows Robert the domestic, private aspect of the afternoon. Robert's real taste of Mardi Gras domesticity turns into an exercise in nausea when he witnesses the reactions to Sally's rape. This situation certainly does not conform to the average tourist's New Orleans fantasy. Gilchrist undercuts both a stereotype of Southern hospitality (what proper upperclass hostess abandons a foreign caller?) and the promise of a drunken good time (what tourist bargains on witnessing the ugliness of rape?).

While Sally is being raped and Robert introduced into the Mardi Gras domestic sphere, Rhoda describes her chance guest to a neighbor:

Vol. 24 (2000): 117 


\section{CREOLIZATION THE NEWORLEANS WAY}

"I have this Englishman I picked up in the Quarter. [. . .] He says he's an engineer. But I keep having this paranoid idea that he might be some sort of a writer ... Like some undercover reporter writing about Mardi Gras for some English magazine. What if he was?' (Gilchrist 242) Rhoda suspects that he just might be a magazine operative, on the literary mission of flushing out the real New Orleans Mardi Gras. Setting aside any paranoid or alcohol-laced implications, Rhoda's idea roots the outsider Robert to the New Orleans travelogue traditions of Tocqueville and Thackeray. In this sense, the seemingly passive Robert not only experiences the episodes of Mardi Gras revelry in a stippled, Tocquevillean style (from hotel room antics to the shock of the street); he also, initially, like the visiting Thackeray, luxuriates in the drunken pleasure of Rhoda and Sally, his two native travel guides. In a final creolized moment, Robert modulates Rhoda's upper-class New Orleans logic with his own stereotyped "British" twist: "'Very unlucky,' he said several times. 'Damned bad luck'" (Gilchrist 245). Against the brutal instance of Sally's rape, this Englishman's "bad luck" almost mirrors Rhoda's "matter of being in the wrong place at the wrong time."

\section{Some Postmodern Reflections}

Confrontation, ethnic integration, and the promises of a drunken good time together characterize creolization the New Orleans way. I have already argued that the various ethnic expressions of creolization link the "universe" of New Orleans to larger cultural discussions. At this moment, I see Jelly Roll Morton's "Hyena Stomp" as either postmodern culture avant la lettre or proto-postmodern culture, in which ambiguous language and hybrid genres are the norm. "If the postmodern is indeed a historical and cultural condition (however transitional or incipient)," notes Andreas Huyssen, "then oppositional cultural practices and strategies must be located within postmodernism, not necessarily in its gleaming façades, to be sure, but neither in some outside ghetto of a properly 'progressive' or a correctly 'aesthetic' art" (200). The "incipient" postmodern design of creolization the New Orleans way relies upon inherent differences; it functions as a sophisticated mode of cultural response to historical changes.

While not implying that aesthetic history collapses around the extraordinary possibilities of New Orleans, I do suggest that several New Orleans methods of creolization share concerns with postmodern works. Beyond the syncretic façades of Charles Moore's Piazza d'Italia and the hesitant multicultural symphony of Vietnamese, Jewish, and Italian immigrants, the history that Ruth McEnery Stuart and Shirley Ann Grau embed into their novels and the critical clichés that surround Ellen Gilchrist's "Drunk Every Day" touch some postmodern sensibilities.

From Stuart's fantasy of a creolized future in the face of social upheaval through Grau's inscription of significant events into the Howlands' genealogical secret, The River's Children and The Keepers of the

Vot. 24 (2000): 118 


\section{THE COMPARATIST}

House offer versions of history and the historical novel that approximate postmodern designs. According to Brian McHale,

Apocryphal history, creative anachronism, historical fantasy-these are the typical strategies of the postmodernist revisionist historical novel. The postmodernist historical novel is revisionist in two senses. First, it revises the content of the historical record, often demystifying or debunking the orthodox version of the past. Secondly, it revises, indeed transforms, the conventions and norms of historical fiction itself. (90)

While the violence of New Orleans during Reconstruction and its sequel of Jim Crow ordinances become Stuart's optimistic venue, haunting Creole matriarchs and vivified portraits underlie Grau's version of Southern inequities. In their own ways and to different ends, Stuart and Grau supplant official history with alternative stories. Stuart's Agnes Le Duc suggests a creolized future to which racial adoption, Creole refinement, and Anglo-Saxon intelligence all contribute. (Against this sanguine future, even the horrors of slavery and the bloody reality of the Civil War can be read as preludes to Agnes's version of multiculturalism.) Grau's Abigail Tolliver, rooted to the outsider's tradition of her great-greatgrandmother and the mind-set of her region and class, cannot see the endemic racism and cultural bigotry that lie outside her family's legacy; to Grau's character, private family history motivates Southern history.

Cloaked in critical clichés, Gilchrist's "Drunk Every Day" also offers a creolized promise with a postmodern edge. "There have always been two contradictory American ideals: to be the occasion of maximum violence, and to remain absolutely innocent," according to Leslie Fiedler in "The New Mutants" (1965), "once, however, these were thought hopelessly incompatible for males [. . .] reserved strictly for women: the spouse of a wife beater, for instance, or the victim of a rape" (206). In his nowclassic essay on the emergence of postmodern fiction and the androgynous aesthetic of the hippie movement, Fiedler discusses violence and innocence as the two absolutes of American culture; normally feminized, in the "new" art, these ideals take on masculine faces. According to Fiedler, "Males have now assumed these classic roles; and just as a particularly beleaguered wife occasionally slipped over the dividing line into violence, so do the new passive protesters" (Fiedler 206). Ellen Gilchrist seems to cast Fiedler's postmodern observation around her creolized New Orleans invitation; in this sense, the fictional Sally is a rape victim and the "feminized" Robert represents an image of foreign innocence, totally removed from the excesses of New Orleans' carnival, who passively "slips over the dividing line" when he assumes the detached, inherently violent attitude of Rhoda (a character who can herself be read as a gender inversion of Fiedler's observation). In a network of drunken parties, hypocritical political stances, and instrumental exploitation, Gilchrist's fictional world of Rhoda's 1975 Mardi Gras reinvents the critical consciousness of Leslie Fiedler's late 1960s.

Vot. 24 (2000): 119 


\section{CREOLIZATION THE NEW ORLEANS WAY}

More than American ideals connect "The New Mutants" to "Drunk Every Day," according to Fiedler:

If whiskey long served as an appropriate symbolic excess for those who chafed against Puritan restraint without finally challenging it - temporarily releasing them to socially harmful aggression and (hopefully) sexual self-indulgence, the new popular drugs provide an excess quite as satisfactorily symbolic to the post-Puritans-releasing them from sanity to madness by destroying in them the inner restrictive order which has somehow survived the dissolution of the outer. (208)

Like Fiedler, Gilchrist overemphasizes the role of alcohol and drugs in the creative process. In hindsight, the narrating Rhoda admits that booze and amphetamines enhanced her carnival experience. (Like a rogue Beat poet or a character in a William Burroughs novel, Rhoda creatively seizes her objet trouvé Robert while she is still high on the dexedrine that she quaffed before visiting the Tchoupitoulas Indians.) While Rhoda's substance abuse results in a "socially harmful" form of apathy (at least where her shotgun partner Sally is concerned), the liquor and pills bring no sexual gratification; her randy quest leads nowhere. Fiedler's parenthetical hope of carnal self-fulfillment evaporates when it collides with the social reality of an unfulfilled upper-class New Orleans housewife, who drinks and abuses drugs to escape from her everyday boredom of luncheons and tennis.

I believe Andreas Huyssen when he claims that oppositional cultural methods and tactics must be found inside postmodernism in order to substantiate its historical and critical validity; in short, the issues at stake in postmodernism are process and sensibility. Rather than looking for the formulaic postmodern work, style, or author, we should more productively ponder the shared processes and sensibilities that have become identified with postmodernity, namely Huyssen's "promise of a 'post-male,' 'post-humanist,' and 'post-Puritan' world," which incorporates multiple voices and perspectives. From Ruth McEnery Stuart's optimistic model of a creolized future through Ellen Gilchrist's uncanny connection to Leslie Fiedler's "The New Mutants," my version of the convoluted logic of creolization the New Orleans way introduces the possibilities of reading just one city's sensibilities and evolving mode of cultural response to historical changes. Outside New Orleans, many unique local cultures and processes await consideration.

Bilkent University (Ankara, Turkey)

\section{NOTES}

1 In an earlier essay ("Succulent Tomatoes"), I discuss the derisive cultural, racial, and historical definitions of New Orleans' "original" settlers, from the political contests of the late nineteenth century to the parodic sensibilities of today. Like other phenomena on this "inland island," the meanings of Creole have developed in ways that respond to conflict and isolation.

Vot. 24 (2000): 120 


\section{THE COMPARATIST}

2 I would like to thank Professor Michael Picone of the University of Alabama for his valuable comments and suggestions, particularly concerning New Orleans' meandering classifications and labels.

3

Professor Roach's book elegantly describes the various products and consequences of Creole "reciprocal acculturation" from the city's burial code through the political events and fanfare of carnival. Through both conversations and his text, Roach's provocative New Orleans work informs many of my ideas in this essay.

4 “Arrival at New Orleans. Forest of ships. Mississippi three-hundred feet deep. External appearance of the city. Beautiful houses. Huts. Muddy streets without pavements. Spanish architecture: flat roofs; English: bricks, small doors; French: massive portes cocheres. Population also mixed. Faces with every nuance of color. Language French, English, Spanish, Creole. General French look, however posters and commercial announcements mostly in English" (Translation mine).

5 "The evening at the theater .. . Strange sight presented in the auditorium: first loge, white; second, gray. Women of color, very pretty ... Third loge black" (Translation mine).

6 For examples of these "ethnic works," see Vujnovich, Shofner and Ellsworth, and Reinecke.

7 I received Mrs. Stern's unpublished account of the German experience in New Orleans from Professor Richard Beavers of the University of New Orleans.

8

This report is cited in John Duffy's Sword of Pestilence: The New Orleans Yellow Fever Epidemic of 1853.

9

Alan Lomax's Mister Jelly Roll consists of oral history, interviews, and second-hand reporting; the comments that I cite come from Jelly Roll's initial interview with Lomax at the Library of Congress.

10

There are several recorded versions of "Hyena Stomp" now available on compact disk, from early jazz anthologies to Jelly Roll Morton collections. My comments follow the 1992 redigitized recording referenced in the Works Cited.

\section{WORKS CITED}

Duffy, John. Sword of Pestilence: The New Orleans Yellow Fever Epidemic of 1853. Baton Rouge: Louisiana State UP, 1966.

Fiedler, Leslie. "The New Mutants." A Fiedler Reader. New York: Stein and Day, 1977: 189-210.

Forsyth, Craig. "Rag Lady and Her Kind: A Socio-Narrative of New Orleans Street Society." Eds. Mackie J-V Blanton and John Cooke. Perspectives on Ethnicity in New Orleans (1981): 46-55.

Gilchrist, Ellen "Drunk Every Day." Rhoda: A Life in Stories. Boston: Little Brown, 1995: 227-246.

Grau, Shirley Ann. The Keepers of the House. Baton Rouge: Louisiana State UP, 1992.

Huyssen, Andreas. After the Great Divide. Bloomington: Indiana UP, 1986.

Vot. 24 (2000): 121 


\section{CREOLIZATION THE NEWORLEANS WAY}

Komins, Benton J. "Succulent Tomatoes, Extraordinary People and Intriguing Performances: Some Literary and Cultural Encounters with New Orleans' Creoles." Comparative Literature Studies 36.1 (Spring 1999): 45-67.

Korn, Bertram. The Early Jews of New Orleans. Waltham: American Jewish Historical Society, 1969.

Lomax, Alan. Mister Jelly Roll. New York: Grosset and Dunlap, 1950.

Morton, Ferdinand (Jelly Roll). "Hyena Stomp." Original Rec. 4 June 1927. Jelly Roll Morton: Original Versions of the Music Inspiring Jelly's Last Jam. BMG Music, 1992.

McHale, Brian. Postmodernist Fiction. New York: Methuen, 1987.

Nash, Jesse William. Vietnamese Values: Confucian, Catholic, American. Diss. Tulane U, 1987.

New Orleans Medical and Surgical Journal 60. New Orleans: 1852-1853.

Reinecke, George. "The National and Cultural Groups of New Orleans, 17181918." New Orleans Ethnic Cultures. New Orleans: The Committee on Ethnicity in New Orleans, 1978. 6-23.

Roach, Joseph. Cities of the Dead: Circum-Atlantic Performance. New York: Columbia UP, 1996.

Rose, Al. Storyville, New Orleans: Being an Authentic, Illustrated Account of the Notorious Red-Light District. Tuscaloosa: U of Alabama P, 1974.

Russell, Beverly. Architecture and Design 1979-1990. New York: Harry N. Abrams, 1989.

Shofner, Jerrell H. and Linda V. Ellsworth, Ethnic Minorities in Gulf Coast Society. Pensacola: Gulf Coast History and Humanities Conference, 1979.

Starr, S. Frederick. New Orleans Unmasqued; Being a Wagwit's Sketches of a Singular American City. New Orleans: Edition Dedeaux, 1985.

Stern, Harriet. The Germans in New Orleans. Unpublished essay.

Stuart, Ruth McEnery. The River's Children: An Idyll of the Mississippi. New York: Century, 1904.

Tallant, Robert. The Romantic New Orleanians. New York: Dutton, 1950.

Thackeray, William Makepeace. Roundabout Papers. New York: Collier, 1899.

Tocqueville, Alexis de. "Voyages en Sicile et aux Etats-Unis." Euvres Complètes Tome V. Ed. J.-P. Mayer. Paris: Gallimard, 1957.

Vujnovich, Milos. Yugoslavs in Louisiana. Gretna: Pelican, 1944.

Vot. 24 (2000): 122 